\title{
Impact of Manufacturing Flexibility on Business Performance: Malaysian's Perspective
}

\author{
Kong Woun Tan, ${ }^{* 1}$ Kong Teong Lim ${ }^{1}$ \\ ${ }^{1}$ Universiti Utara Malaysia, Malaysia
}

\begin{abstract}
This research aims to investigate the impact of manufacturing flexibility on business performance. The manufacturing flexibility dimensions are mix, new product, labor, machine, material handling, routing and volume flexibility. The measures for the business performance are product market performance, customer satisfaction and profitability. The impact of manufacturing flexibility on business performance has been tested using a cross sectional study employing survey methodology, conducted within five manufacturing industries in Malaysia. Data were obtained from 137 returned questionnaires, which were analyzed using correlational and regression analyses. The results of the correlation analyses indicated that the manufacturing flexibility dimensions were positively and highly correlated among themselves, thus suggesting that the dimensions were interdependent. Meanwhile, the findings of the regression analyses provided support for the idea that manufacturing flexibility has a positive and significant impact on business performance. In other words, manufacturing flexibility improves business performance. In conclusion, this empirical research provides insights and a better understanding about the relationship between manufacturing flexibility and business performance. This research allows researchers/practitioners to gain in-depth knowledge about the concept of manufacturing flexibility and its impacts.
\end{abstract}

Keywords: manufacturing flexibility, business performance, product market performance, customer satisfaction, profitability, multicollinearity, Malaysia

JEL Classification: L1, L6 


\section{Introduction: Manufacturing Flexibility as an Important Competitive Priority}

The world's business environment is filled with uncertainty, which has led to the need for flexibility, where customers expect faster responses and flexible options (Zhang, et al. 2003, Agus 2011). The emergence of manufacturing flexibility has outclassed traditional manufacturing approaches in securing a competitive advantage for organizations (Kaur, et al. 2016).

Rapid changes in the world's technology, with a shortened product's life cycle and demanding customers that aim for more innovative products with higher value, have made creating a flexible organization essential (Judi and Beach 2008, Russell and Taylor 2014). Decreasing profit margins, increasing global competition and the speed of technological changes (Judi and Beach 2008, Kaur, et al. 2016, Mishra, et al. 2014) have further accelerated the need for flexibility. Since manufacturing flexibility enhances the ability of a company to respond to customer needs that are vastly diversified, it is generally accepted that, by incorporating manufacturing flexibility, it will help the organization to respond to changes and customer needs in a better way (Rogers 2008, Mishra, Pundir, and Ganapathy 2016, Mishra, et al. 2014, Pérez Pérez, et al. 2016). As flexibility becomes vital and its aptitudes are recognized by executives around the world, it has been asserted as the "next competitive battle" (Vokurka and O'Leary-Kelly 2000, Brettel, et al. 2016). Manufacturing flexibility has been recognized as an important manufacturing capability that has the capabilities to impact both the competitive situation and the business situation of a company
(Vokurka and O’Leary-Kelly 2000, Brettel, Klein, and Friederichsen 2016). As mass customization gradually becomes a substitution for mass production, the importance of manufacturing flexibility has been upheld to a degree where the understanding of its effect on business performance is vital to ensure the efficient management of this best practice (Russell and Taylor 2014).

This paper understands the above current issues and tries to explore the role of manufacturing flexibility in business performance while it contributes to the body of knowledge on the impacts of manufacturing flexibility on manufacturing sectors through a cross-sectional survey research. Meanwhile, a more holistic and parsimonious incorporation of manufacturing flexibility, to enhance business performance, is also introduced. In addition, this study makes a methodological contribution where multicollinearity issues among the indicators of manufacturing flexibility have been solved using principal components analysis, followed by a simple regression analysis on the principal components' scores.

This paper focuses on manufacturing flexibility in the context of Malaysian manufacturing firms, as it is the main driver of Malaysia's prosperity, which makes understanding the effects of manufacturing flexibility on business performance crucial. The remainder of this paper proceeds as follows: the next section presents the relevant literature, followed by the hypotheses development, research design and methodology, sampling justifications, data screening, data analysis, limitations and a discussion of the results, future research recommendations, and ends with the conclusion of the paper. 
Literature Review: The Inconsistent Evidence Regarding the Effect of Manufacturing Flexibility and the Chaotic Relationships between Manufacturing Flexibility and Business Performance

Regardless of the dimensions of manufacturing flexibility, past research has provided inconsistent evidence regarding the impact of manufacturing flexibility on business performance (Chang et al. 2003, Vokur$\mathrm{ka}$ and O'Leary-Kelly 2000). According to Rogers (2008); the lack of understanding about the relationship between the individual dimensions of manufacturing flexibility and organizational performance could be the reason for the inconsistent results. Different manufacturing flexibility dimensions affect performance in dissimilar ways, and the sets of manufacturing flexibility dimensions create a combined effect (Ramasesh and Jayakumar 1991, Pérez-Pérez et al. 2018).

Misunderstanding and ignorance of the difference in the definition of manufacturing flexibility and its concept, whether referring to the organization or manufacturing system, can cause confusion in the literature, and in practical applications. Difficulty with its measurement arises when manufacturing flexibility is treated as the ability of the whole organization. This haphazard exists because different functional areas of an organization may require different dimensions of flexibility. As an example, mix flexibility may be more relevant to a manufacturing system for its manufacturing function, compared to other business functions. In addition, different characteristics of manufacturing systems may have dissim- ilar responses to different sets of flexibility dimensions (Shewchuk and Moodie 1998).

This research defined manufacturing flexibility as "a multidimensional construct that represents the overall ability of the manufacturing system to adapt to both external changes and internal change" (Rogers 2008, Chauhan and Singh 2014). In other words, manufacturing flexibility is the specific characteristic of a manufacturing system.

Positive results of manufacturing flexibility on business performance have been supported by various past researches. Swamidass and Newell (1987) studied the effects of manufacturing flexibility on business performance, with a focus on growth. The research done by Swamidass and Newell delivers a statistically significant result with the fact that greater manufacturing flexibility provides better performance results, while research by Ramasesh and Jayakumar (1991) has shown that manufacturing flexibility can improve financial performance, when measured by net revenue. Besides, Narasimhan and Das (1999) have provided empirical evidence to support the idea that new product flexibility has a positive relationship with customer satisfaction. Research by Swink, Narasimhan, and Kim (2005) indicated that both process and new product flexibilities have a positive impact on market-based performance. In the meantime, a study by Agus (2011) investigated the relationship between Supply Chain Management (SCM), supply chain flexibility and business performance (return on assets, return on sales, and financial performance). Significant correlations occurred between supply chain management and supply chain flexibility, and also business performance. The findings of Agus's study also infer that supply chain management can enhance the performance of Malaysian man- 
ufacturing organizations through the use of supply chain flexibility as a partial mediator.

On the other hand, Gupta and Somers (1996) have conducted research to investigate the relationship among business strategy, manufacturing flexibility, and organization performance, in terms of financial performance and growth performance. Inconsistent results regarding the impact of manufacturing flexibility on business performance have been seen. The results of the path analysis showed that only process flexibility has a marginal significant direct effect on a firm's financial performance (negative result $(-0.111)$ at $\alpha=0.10$ ), while only five of the nine dimensions of manufacturing flexibility (expansion, process, routing, products/production, and volume flexibilities) have a direct effect on growth performance. Details of the research show that expansion flexibility and volume flexibility exhibited positive and significant results towards growth performance, at $\alpha=$ 0.01 , routing flexibility at $\alpha=0.05$, while products flexibility and process flexibility exhibited negative results towards growth performance, at $\alpha=0.05$ and $\alpha=0.10$ respectively.

Similarly, Rogers (2008) has also stressed the lack of empirical evidence supporting whether manufacturing flexibility improves performance. In the same vein, a recent study by Mishra, Pundir, and Ganapathy (2014) presented a systematic review of 101 research papers, related to manufacturing flexibility, available in academic journal databases published from 1992 to January 2013, which stressed that not all past research found that manufacturing flexibility improves business performance, and it is a gap worth exploring further. In addition, a study done by PérezPérez et al. (2018) has further consolidated the view that there have been plenty of research opportunities into the context of manufacturing flexibility, and the content of manufacturing flexibility is still contentious. Appendix I shows a brief summary of the past research undertaken, based on this paper's literature review, where the author and year, type of study, the findings and remarks are tabled.

Nevertheless, the literature reviewed from 1987 to 2018 dictates that the nonexistence of parsimony set for manufacturing flexibility's dimensions is also worth exploring. Specifically, the above discussions fail to reveal how manufacturing flexibility leads to better firm performance, which is still unknown.

\section{Indicators Chosen for This Research}

The indicators chosen for this research have evolved from past literature reviews, where they represent the most popular manufacturing flexibility dimensions that have been researched for the past 30 years (19872018). Meanwhile, the indicators for business performance are established from common business performance indicators employed in past manufacturing flexibility studies.

\section{Indicators for Manufacturing Flexibility and Their Definition}

Table 1. Definition of Manufacturing Flexibility's Indicators for This Research

\begin{tabular}{|c|c|c|}
\hline $\begin{array}{l}\text { Manufacturing } \\
\text { Indicators }\end{array}$ & Flexibility & Definition \\
\hline Mix Flexibility & & $\begin{array}{l}\text { g system to switch between different products } \\
\text { ach, 2008). }\end{array}$ \\
\hline
\end{tabular}


Gadjah Mada International Journal of Business - Sept.-Dec., Vol. 21, No. 3, 2019

Table 1. Continued

\begin{tabular}{|c|c|}
\hline Volume Flexibility & $\begin{array}{l}\text { "The ability of the manufacturing system to alter the output volume of a man- } \\
\text { ufacturing process" (Judi, Beach, and Muhlemann 2004, Sethi and Sethi 1990) } \\
\text { and Muhlemann 2004, Sethi and Sethi } 1990 .\end{array}$ \\
\hline New Product Flexibility & $\begin{array}{l}\text { "The ability of the manufacturing system to incorporate new product(s) into } \\
\text { the existing range of products" (Gupta and Somers 1996, Judi and Beach 2008). }\end{array}$ \\
\hline Machine Flexibility & $\begin{array}{l}\text { "The ability of the manufacturing machine to perform more than one oper- } \\
\text { ation to produce different parts or products" (Al-jawazneh 2012, Lucas and } \\
\text { Kirillova 2011, Rogers, Ojha, and White 2011, Sethi and Sethi 1990) }\end{array}$ \\
\hline Material Handling Flexibility & $\begin{array}{l}\text { "The ability of the material handling system to handle various types of mate- } \\
\text { rials, where dissimilar part are handled well without affecting the performance } \\
\text { of the existing system" (Helkiö 2008). }\end{array}$ \\
\hline Labor Flexibility & $\begin{array}{l}\text { "The ability of production workers to perform more than one task in the man- } \\
\text { ufacturing system" (Rogers, Ojha, and White 2011). }\end{array}$ \\
\hline Routing Flexibility & $\begin{array}{l}\text { "The ability of the manufacturing system to manufacture products through } \\
\text { a variety of different routes" (Nishith, Rishi, and Sharma 2013, Rogers 2008, } \\
\text { Rogers, Ojha, and White 2011, Zhang, Vonderembse, and Lim 2003, Sethi and } \\
\text { Sethi 1990). }\end{array}$ \\
\hline
\end{tabular}

\section{Indicators for Business Performance}

In general, business performance is a measure of the accomplishment of a firm's goals (Richard et al. 2009). According to Richard et al. (2009), the construct of business performance includes the following firm outcomes: (i) financial performance (such as profit margin, return on investment); (ii) product market performance (market share and its growth); and (iii) shareholders' returns (such as dividends, return on equity, cash value added).

Common business performance indicators employed in the past manufacturing flexibility studies include product market performance (sales/market share), profits, and customer satisfaction (Richard et al. 2009). According to various past researches (Mann and Kehoe 1994, Nawanir 2011, Nawanir, Lim, and Othman 2013), business performance is referred to as "the outcomes which are due to the interaction among all value creation activities and the firm's environment."
The indisputable fact that profit, growth and pleasing the customers are the three main reasons for the existence of a business firm, any attempt to measure a firm's business performance, must include these three indicators, i.e. profitability, product market performance and customer satisfaction. In this research, business performance is conceptualized to include the following facets: profitability, product market performance (that includes sales growth and market share) and customer satisfaction.

\section{Profitability}

The ability to consistently generate profits is critical to the survival of a firm. Profitability, a financial indicator, measures a firm's ability to generate returns or earn profits (Miller, et al. 2013, Santos and Brito 2012). It is one of the most commonly used indicators to represent firm performance (Carton and Hofer 2006). Profitability measures encompass values and ratios which incorporate net income or operating income (Santos and Brito 2012). 


\section{Product Market Performance}

The product market performance refers to the performance of a firm's major product line, in terms of it achieving its sales and market share growth objectives (Richard et al.

\section{Independent Variable}

improve business performance (Al-jawazneh 2012, Rogers 2008, Stevenson 2015).

\section{Theoretical Framework and}

Hypotheses

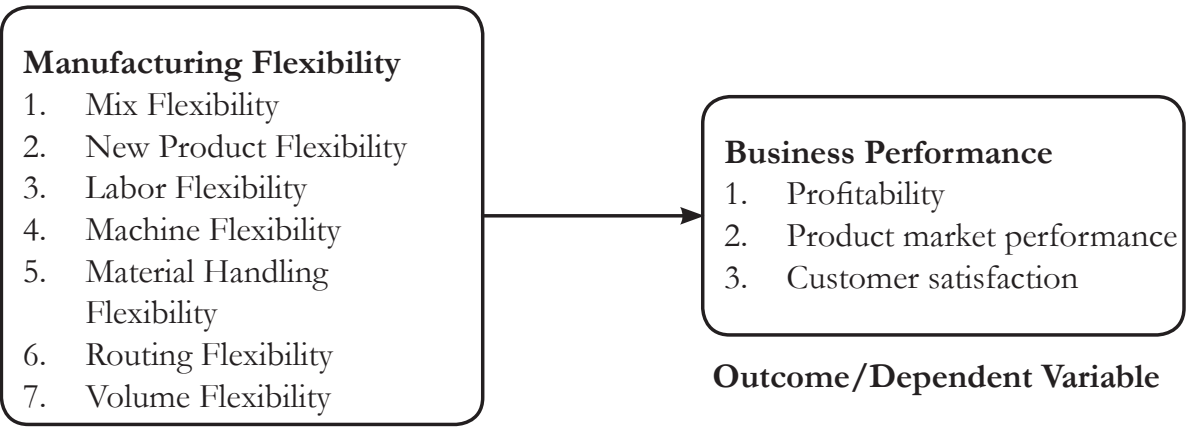

Figure 1. Research Framework for the Relationships between Manufacturing Flexibility and Business Performance

2009). Market share (defined as the percentage of a market in terms of either units or revenue accounted for by a product) and market share growth (referred to as the increment of market share over a specific period of time) are known as important indicators for market competitiveness, and are often used to gauge how well a firm is doing, relative to its competitors (Wikipedia 2015, Indarti 2004).

\section{Customer Satisfaction}

Customer satisfaction is a key indicator of how good a product or service, provided by a firm, is. In real life, customer satisfaction is not only achieved by providing tangible products that fulfil the customers' needs, but it also depends on the superior services/after-sales-services provided. This superiority in products and services can foster customer loyalty, and through word-of-mouth, can subsequently

\section{Hypothesis}

H: Manufacturing flexibility has a positive relationship with business performance.

Manufacturing flexibility was hypothesized to have a positive relationship with business performance, because manufacturing flexibility allows an organization to adapt successfully to environmental changes, such as changes in its customers' requirements and market conditions. This leads to the following specific hypotheses:

$H_{a}$ : Manufacturing flexibility has a positive relationship with profitability.

$H_{b}$ : Manufacturing flexibility has a positive relationship with product market performance.

$H_{:}$: Manufacturing flexibility has a positive relationship with customer satisfaction. 


\section{Research Design and Methodology}

This research adopted a cross-sectional study using survey methodology, where data were collected only once, at the same and single point in time (Cooper and Schindler 2013). Data were collected from selected manufacturing firms in Malaysia (listed in the Malaysian Investment Development Authority (MIDA) directory and Federation of Malaysian Manufacturers (FMM) directory) using a structured questionnaires.

One thousand firms, which were selected using proportional stratified random sampling, from five different industrial sectors (the electrical and electronics related sector, machine and equipment fabricators, chemicals and chemical products producers, food products and beverages manufacturers and also metal-related products). This sampling methodology was chosen because it minimized the sample's selection bias and helped the researcher to obtain a sample population that best represented the entire population being studied (Sekaran and Bougie 2013).

The survey data were collected through printed questionnaires that were distributed to the respondents who possess adequate knowledge of manufacturing flexibility and their firm's performance data. Since this information was accessible to the executive management, therefore the firms' production managers, directors of manufacturing or the heads of the production departments were the targeted respondents.

The unit of analysis of the current research was the manufacturing plant. This was chosen because it was predicted to reflect, to a certain degree, all of the seven manufacturing flexibility dimensions included in this research (Koste, Malhotra, and Sharma 2004). Meanwhile, analysis at the level of the manufacturing plant is also aligned with the past empirical research related to manufacturing flexibility (Larso, Doolen, and Hacker 2009, Koste, Malhotra, and Sharma 2004, Pérez-Pérez et al. 2018).

Statistical Package for the Social Sciences (SPSS) was employed for the data analyses. The data collected was analyzed using descriptive analysis, where the percentage and the mean value for specific variables were calculated. In addition, correlation analysis and regression analysis were conducted to investigate the relationship between manufacturing flexibility and business performance. The next section will discuss the sampling justifications, data screening, the respondents' profiles, the construct's validity, reliability and description statistics.

\section{Sampling Justifications, Data Screen- ing, Respondents' Profiles, Construct Validity, Reliability and Description \\ Statistics}

One hundred and forty-three usable questionnaires were obtained, while the sampling justifications and data screening for the outliers were as follows.

\section{Sampling Justifications}

According to Sekaran and Bougie (2013), a sample size five times more than the number of independent variables is preferred, where a sample size larger than 30 but less than 500 is appropriate for most research. A sample size larger than 500 is not desirable, as statistical significance can be 
identified even with only weak relationships (correlation as low as 0.10) existing among them. Based on the generalized scientific guideline for sample size decisions for a given population size, as provided by Sekaran and Bougie (2013), the suggested sample size for this study was about 340 firms.

However, the minimum number of sample size required for a study also depends upon the type and complexity of the research, and the analysis technique employed (Hair, Black, Babin, and Anderson, 2013; Sekaran and Bougie, 2013). As an example, Hair et al. (2013) suggested for a multiple regression analysis, a minimum ratio of samples to the independent variables of 5:1, with a more desirable level being 15 to 20 samples for each independent variable. Seven independent variables in the current research made a sample size of 105 to 140 sufficient for our regression analysis, while the correlation could be done with a sample size as small as 30 (Hair et al. 2013; Sekaran and Bougie, 2013).

\section{Data Screening for Outliers}

The purpose of data screening was to identify outliers from the data, to ensure that the data obtained were suitable for further analyses (where bad data can be ruled out). Screening of the outliers ensures that the normality assumption is fulfilled before further analyses were carried out.

Table 2 provided the summary of the outliers' identification, from the perspective of the univariate, bivariate and multivariate items . Six outlier cases were identified (case numbers 16, 84, 99, 5, 23 and 9). Specifically, these six cases are discarded from the subsequent analyses. Therefore, the analyses that followed, and all the reported statistics after this subsection, are based on 137 cases. The sample size of 137 cases is sufficient to be analyzed by this research, as sample sizes larger than 30 and smaller than 500 are suitable for this type of research (Sekaran and Bougie 2013). Section 3.1.1 provides the sampling justifications for this study, and the 137 samples fulfilled those requirements with ease.

Table 2. Results of Univariate, Bivariate and Multivariate Outlier Identification

\begin{tabular}{cccc}
\hline Case ID & $\begin{array}{c}\text { Mahalanobis } \\
\text { Distance }\end{array}$ & Enivariate & Bivariate \\
\hline 16 & 58.959 & 2 & 23 \\
\hline 84 & 50.222 & 3 & 9 \\
\hline 99 & 46.555 & 0 & 15 \\
\hline 5 & 38.371 & 3 & 19 \\
\hline 23 & 37.252 & 1 & 19 \\
\hline 2 & 34.730 & 0 & 0 \\
\hline 43 & 33.217 & 0 & 0 \\
\hline 62 & 32.130 & 0 & 0 \\
\hline 135 & 31.155 & 0 & 0 \\
\hline 104 & 29.196 & 0 & 0 \\
\hline 6 & 29.018 & 0 & \\
\hline & & &
\end{tabular}


Gadjah Mada International Journal of Business - Sept.-Dec., Vol. 21, No. 3, 2019

Table 2. Continued

\begin{tabular}{ccccc}
9 & 28.069 & 1 & 15 \\
\hline 41 & 27.023 & 0 & 0 \\
\hline 42 & 25.867 & 0 & 0 \\
\hline 11 & 25.297 & 0 & 0 \\
\hline
\end{tabular}

Notes: Sorted based on value of Mahalanobis Distance; *Frequency of certain cases considered as outliers

\section{Distribution of Population and Sample}

According to Table 3 , the sample provides diverse and representative industrial coverage.
2013). Construct validity can be assessed with discriminant validity and convergent validity (Sekaran and Bougie 2013). According to Zikmund et al. (2013), discriminant validity refers to the uniqueness of a measure, while convergent validity means constructs or

Table 3. Distribution of Population and Sample

\begin{tabular}{lrrrr}
\hline Industry & Population & $\mathbf{\%}$ & Frequency & $\mathbf{\%}$ \\
\hline Basic metals and fabricated metal products & 910 & $28.8 \%$ & 31 & $22.6 \%$ \\
\hline Machinery \& equipment & 745 & $23.5 \%$ & 26 & $19.0 \%$ \\
\hline Electronic, electrical equipment and components & 517 & $16.3 \%$ & 34 & $24.8 \%$ \\
\hline Chemicals and chemical products & 493 & $15.6 \%$ & 21 & $15.3 \%$ \\
\hline Food products and beverages & 500 & $15.8 \%$ & 25 & $18.2 \%$ \\
\hline Total & $\mathbf{3 1 6 5}$ & $\mathbf{1 0 0 . 0} \%$ & $\mathbf{1 3 7}$ & $\mathbf{1 0 0 . 0}$ \\
\hline
\end{tabular}

\section{Construct Validity and Reliability}

Generally the three types of validity that are considered are: (1) content validity; (2) criterion-related validity; (3) construct validity (Saraph, Benson, and Schroeder 1989).

The instrument in the questionnaire was pre-tested and reviewed by three academicians from the field of operations management, and three industry practitioners, to ensure the contents' validity. In this research, correlations between the manufacturing flexibility dimensions and business performance measures will be established to ensure that criterion-related validity is satisfied (Saraph, Benson, and Schroeder 1989).

Construct validity is important to ensure that whatever is concluded from an investigation can be shared confidently (Hair et al. measures that "should be related to one another are in fact related." Measures can have only one of the types of construct validity.

The construct validity of each manufacturing flexibility dimension and each business performance measure are evaluated by factor analyzing the measurement items of each of the measures/dimensions. If the items measuring the same construct formed a single factor, this can be used as tentative evidence of construct validity for that particular construct. The statistical summary of the factor analysis performed on the variables being studied is shown in Table 4. According to the tables, all the KMO values are greater than 0.70 (good) except product market performance with value of 0.50 (mediocre). Other than that, Bartlett's test of sphericity 
Tan and Lim

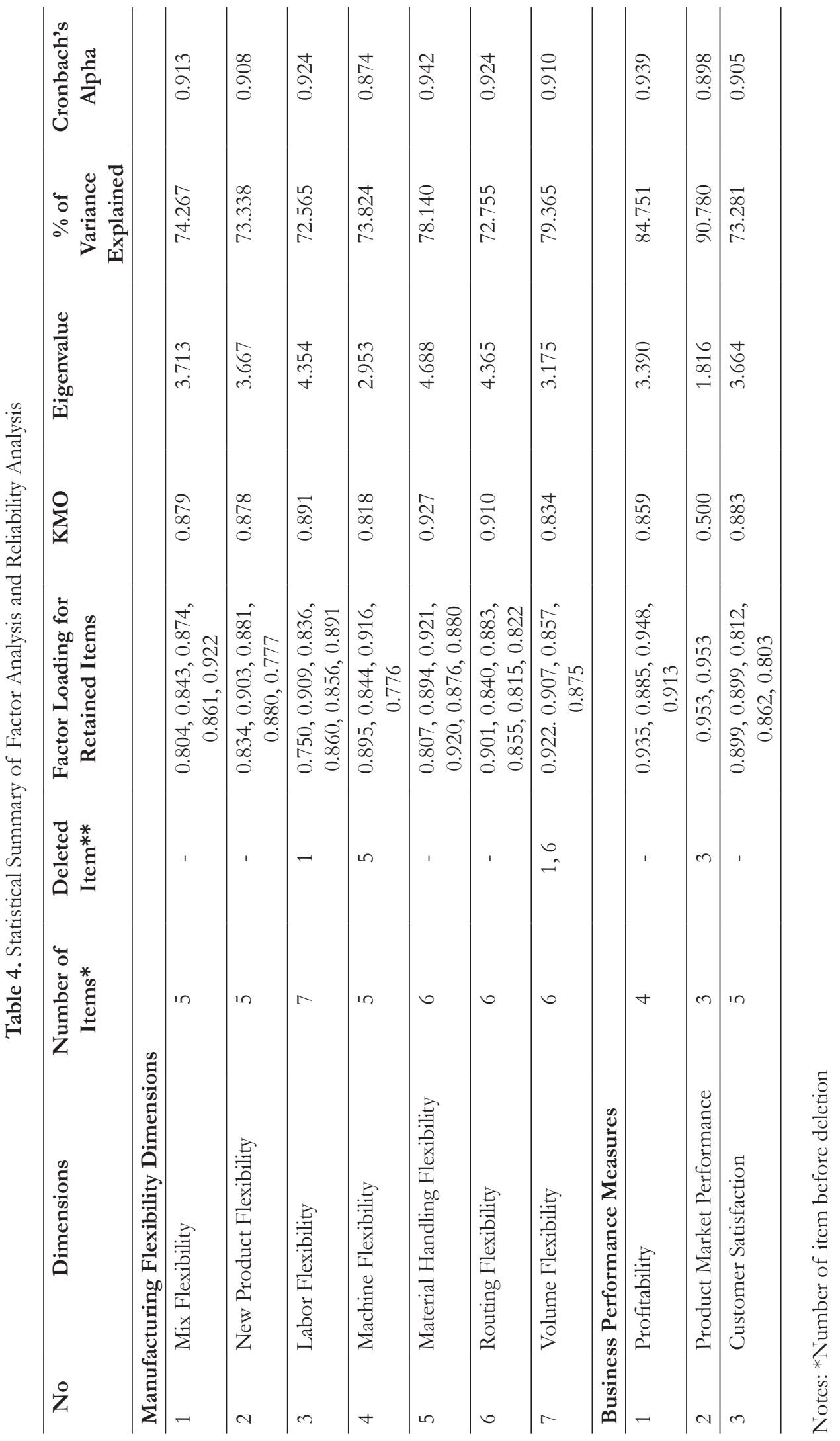


is also significant at $\alpha=0.05$, which means there are significant correlations amongst at least some of the measurement items (Hair et al. 2013). In addition, only items that have a factor loading of at least 0.70 are retained. A factor loading of 0.70 was chosen to warrant that the variance explained is more than $50 \%$, which indicates a well-defined factor structure (Hair et al. 2013).

Based on both tables, the factor loadings for all the retained constructs ranged from 0.75 to 0.95 . It was assured that the items deleted did not affect the content validity of the measures in a negative way. Furthermore, all the constructs have a "percentage of variance explained" ranging between $72.57 \%$ and $90.78 \%$ (a high percentage of variance explained means that those regressions give a good fit). The above findings provide sufficient support to the construct validity for all the measures employed in this research.

Reliability analysis is performed to ensure the internal consistency and stability of the measurement items used to measure a construct (Roberts and Priest 2006). Cronbach's alpha is commonly used to assess reliability, where alpha values greater than 0.70 are treated as constructs with good reliability (Hair et al. 2013). The results of the reliability analysis for each construct are exhibited in Table 4, where all the values of Cronbach's alpha are greater than 0.70 (values range between 0.91 and 0.94). These mean the internal consistency for all the measures are satisfactory. In sum, the measures used in this research are considered valid and reliable.

\section{Descriptive Statistics of Variables}

This section discusses the descriptive statistics of the manufacturing flexibility dimensions and business performance measures. The minimum value, maximum value, mean and standard deviation of the data are depicted in Table 5. Those measurements were performed by using the perceptual scale, where each question was answered using the following six-point Likert scale that represented the level of agreement, from strongly disagree

Table 5. Descriptive Statistics of the Variables

\begin{tabular}{lccccc}
\hline Descriptive Statistics & N & Minimum & Maximum & Mean & Std. Deviation \\
\hline Manufacturing Flexibility Dimensions & & & & \\
\hline Mix Flexibility & 137 & 2.000 & 6.000 & 4.438 & 0.815 \\
\hline New Product Flexibility & 137 & 2.000 & 6.000 & 4.003 & 0.857 \\
\hline Labor Flexibility & 137 & 2.500 & 6.000 & 4.320 & 0.750 \\
\hline Machine Flexibility & 137 & 2.000 & 5.250 & 4.058 & 0.800 \\
\hline $\begin{array}{l}\text { Material Handling Flex- } \\
\text { ibility }\end{array}$ & 137 & 3.000 & 6.000 & 4.406 & 0.717 \\
\hline Routing Flexibility & 137 & 2.000 & 5.670 & 3.989 & 0.785 \\
\hline $\begin{array}{l}\text { Volume Flexibility } \\
\text { Business Performance Measures }\end{array}$ & 137 & 2.500 & 6.000 & 4.456 & 0.802 \\
\hline $\begin{array}{l}\text { Profitability } \\
\text { Product Market Perfor- }\end{array}$ & 137 & 2.000 & 6.000 & 4.296 & 0.794 \\
\hline $\begin{array}{l}\text { mance } \\
\text { Customer Satisfaction }\end{array}$ & 137 & 2.000 & 5.000 & 4.040 & 0.793 \\
\hline
\end{tabular}


(one), disagree (two), somewhat disagree (three); somewhat agree (four); agree (five) to strongly agree (six). The descriptive statistics portrayed the mean of the manufacturing flexibility dimensions, ranging from 3.99 to 4.46, with the standard deviation ranging between 0.72 and 0.86 , which inferred that Malaysian manufacturing firms have been implementing manufacturing flexibility dimensions in their manufacturing systems, whether deliberately or by chance. Meanwhile, high mean values of the business performance measures were also detected. The mean values ranged between 4.04 and 4.37, with the standard deviation ranging between 0.72 and 0.79 .

\section{Empirical Research: Correla- tion, Principal Component Analysis and Regression}

\section{Associations between the Variables: Pearson Correlation Analysis}

Based on the Pearson correlation analyses tabled in Table 6 , all the dimensions of manufacturing flexibility are inter-correlated, and all the manufacturing flexibility dimensions are positively and significantly associated with all the measures of business performance.

\section{Multiple Regression Analysis}

Table 7 shows the results of multiple regression analyses using business performance measures as the dependent variables. Significant relationships are found between the manufacturing flexibility dimensions (independent variables) and each of the business performance measures (dependent variables).

Regression analysis shows that profitability has the highest adjusted R2 value, where $66.30 \%$ of its variances are explained by variances in the manufacturing flexibility dimensions, while product market performance and customer satisfaction registered $60.70 \%$ and $53.30 \%$ respectively. While F-statistics show the significant relationship

Table 6. Correlation among Dimensions

\begin{tabular}{|c|c|c|c|c|c|c|c|c|}
\hline \multirow[t]{2}{*}{ No } & \multirow[t]{2}{*}{ Dimensions } & \multicolumn{7}{|c|}{ Manufacturing Flexibility Dimensions } \\
\hline & & 1 & 2 & 3 & 4 & 5 & 6 & 7 \\
\hline \multicolumn{9}{|c|}{ Manufacturing Flexibility } \\
\hline 1 & Mix & 1 & & & & & & \\
\hline 2 & New Product & $0.294 * *$ & 1 & & & & & \\
\hline 3 & Labor & $0.424 * *$ & $0.549 * *$ & 1 & & & & \\
\hline 4 & Machine & $0.507 * *$ & $0.592 * *$ & $0.578^{* *}$ & 1 & & & \\
\hline 5 & Material Handling & $0.425^{* *}$ & $0.562^{* *}$ & $0.788^{* *}$ & $0.596^{* *}$ & 1 & & \\
\hline 6 & Routing & $0.311^{* *}$ & $0.578^{* *}$ & $0.655^{* *}$ & $0.604 * *$ & $0.620 * *$ & 1 & \\
\hline 7 & Volume & $0.447 * *$ & $0.646^{* *}$ & $0.732 * *$ & $0.641 * *$ & $0.718^{* *}$ & $0.660^{* *}$ & 1 \\
\hline \multicolumn{9}{|c|}{ Business Performance Measures } \\
\hline 8 & Profitability & $0.613^{* *}$ & $0.501 * *$ & $0.656^{* *}$ & $0.493^{* *}$ & $0.675^{* *}$ & $0.645^{* *}$ & $0.633^{* *}$ \\
\hline 9 & $\begin{array}{l}\text { Product Market } \\
\text { Performance }\end{array}$ & $0.593^{* *}$ & $0.397 * *$ & $0.503 * *$ & $0.341^{* *}$ & $0.526^{* *}$ & $0.609 * *$ & $0.481 * *$ \\
\hline 10 & Customer Satisfaction & $0.536 * *$ & $0.472 * *$ & $0.562 * *$ & $0.603 * *$ & $0.633^{* *}$ & $0.587 * *$ & $0.603 * *$ \\
\hline
\end{tabular}


Gadjah Mada International Journal of Business - Sept.-Dec., Vol. 21, No. 3, 2019

between the manufacturing flexibility dimensions and each business performance measure, the t-statistics testing $\mathrm{H}_{0}: \beta_{\mathrm{i}}=0$ shows that only some of the manufacturing flexibility dimensions have significant impacts on business performance. This regression model provides facts that show customer satisfaction is only supported by mix flexibility $(\beta=$ $0.259 ; \mathrm{t}=3.677 ; \mathrm{p}<0.01)$, machine flexibility $(\beta=0.149 ; \mathrm{t}=1.682 ; \mathrm{p}<0.10)$, material handling flexibility $(\beta=0.289 ; \mathrm{t}=2.798 ; \mathrm{p}<$
$0.01)$, and routing flexibility $(\beta=0.230 ; \mathrm{t}=$ 2.617; $\mathrm{p}<0.05)$. Besides, theory contradicts sign of beta and t-statistic have been seen with machine flexibility on profitability $(\beta=$ $-0.388 ; \mathrm{t}=-4.771 ; \mathrm{p}<0.01)$ and product market performance $(\beta=-0.215 ; \mathrm{t}=-2.860 ; \mathrm{p}<$ 0.01 ), which misaligned with theory, common sense and also the Pearson correlation analysis. These suggested the existence of multicollinearity issues in the regression model.

Table 7. Results of Multiple Regression Analysis between Manufacturing Flexibility Dimensions and Business Performance Measures

\begin{tabular}{|c|c|c|c|c|c|}
\hline \multirow{3}{*}{$\begin{array}{l}\text { Manufacturing Flexibility } \\
\text { Dimensions }\end{array}$} & \multicolumn{5}{|c|}{ Dependent Variable: Profitability } \\
\hline & \multicolumn{2}{|c|}{ Unstandardized } & \multirow{2}{*}{$\begin{array}{c}\text { Standardized } \\
\text { Beta }\end{array}$} & \multirow{2}{*}{$\mathbf{t}$} & \multirow{2}{*}{ Sig. } \\
\hline & Beta & Std. Error & & & \\
\hline (Constant) & -0.240 & 0.283 & & -0.848 & 0.398 \\
\hline Mix & 0.409 & 0.058 & 0.420 & 7.020 & 0.000 \\
\hline New & 0.070 & 0.065 & 0.076 & 1.077 & 0.283 \\
\hline Labor & 0.096 & 0.096 & 0.091 & 1.008 & 0.315 \\
\hline Machine & -0.213 & 0.075 & -0.215 & -2.860 & 0.005 \\
\hline Material Handling & 0.283 & 0.097 & 0.256 & 2.913 & 0.004 \\
\hline Routing & 0.350 & 0.075 & 0.346 & 4.641 & 0.000 \\
\hline Volume & 0.056 & 0.087 & 0.056 & 0.639 & 0.524 \\
\hline $\mathrm{R} 2$ & & & 0.681 & & \\
\hline Adjusted R2 & & & 0.663 & & \\
\hline Significant F & & & 0.000 & & \\
\hline \multirow{3}{*}{$\begin{array}{l}\text { Manufacturing Flexibility } \\
\text { Dimensions }\end{array}$} & \multicolumn{4}{|c|}{ Dependent Variable: Product Market Performance } & \\
\hline & \multicolumn{2}{|c|}{ Unstandardized } & \multirow{2}{*}{$\begin{array}{c}\text { Standardized } \\
\text { Beta }\end{array}$} & \multirow{2}{*}{$\mathbf{t}$} & \multirow{2}{*}{ Sig. } \\
\hline & Beta & Std. Error & & & \\
\hline (Constant) & 0.106 & 0.306 & & 0.347 & 0.729 \\
\hline Mix & 0.532 & 0.063 & 0.547 & 8.458 & 0.000 \\
\hline New & 0.081 & 0.070 & 0.087 & 1.151 & 0.252 \\
\hline Labor & -0.034 & 0.103 & -0.032 & -0.328 & 0.743 \\
\hline Machine & -0.384 & 0.081 & -0.388 & -4.771 & 0.000 \\
\hline Material Handling & 0.216 & 0.105 & 0.195 & 2.058 & 0.042 \\
\hline Routing & 0.567 & 0.081 & 0.562 & 6.971 & 0.000 \\
\hline Volume & -0.058 & 0.094 & -0.058 & -0.614 & 0.540 \\
\hline $\mathrm{R} 2$ & & & 0.627 & & \\
\hline Adjusted R2 & & & 0.607 & & \\
\hline Significant F & & & 0.000 & & \\
\hline
\end{tabular}


Tan and Lim

\begin{tabular}{|c|c|c|c|c|c|}
\hline \multirow{3}{*}{$\begin{array}{l}\text { Manufacturing Flexibility } \\
\text { Dimensions }\end{array}$} & \multicolumn{5}{|c|}{ Dependent Variable: Customer Satisfaction } \\
\hline & \multicolumn{2}{|c|}{ Unstandardized } & \multirow{2}{*}{$\begin{array}{l}\text { Standardized } \\
\text { Beta }\end{array}$} & \multirow{2}{*}{$\mathbf{t}$} & \multirow{2}{*}{ Sig. } \\
\hline & Beta & Std. Error & & & \\
\hline (Constant) & 0.677 & 0.301 & & 2.246 & 0.026 \\
\hline Mix & 0.228 & 0.062 & 0.259 & 3.677 & 0.000 \\
\hline New & -0.004 & 0.069 & -0.005 & -0.059 & 0.953 \\
\hline Labor & -0.074 & 0.102 & -0.077 & -0.726 & 0.469 \\
\hline Machine & 0.134 & 0.079 & 0.149 & 1.682 & 0.095 \\
\hline Material Handling & 0.289 & 0.103 & 0.289 & 2.798 & 0.006 \\
\hline Routing & 0.210 & 0.080 & 0.230 & 2.617 & 0.010 \\
\hline Volume & 0.082 & 0.092 & 0.092 & 0.885 & 0.378 \\
\hline $\mathrm{R} 2$ & & & 0.557 & & \\
\hline Adjusted R2 & & & 0.533 & & \\
\hline Significant F & & & 0.000 & & \\
\hline
\end{tabular}

Mitigating the Multicollinearity Issues:

Principal Component Analysis and Simple Regression Analysis

Multiple regression analysis requires that the independent variables are not linearly associated, as high levels of association among the independent variables create multicollinearity issues (Kuhn and Johnson 2013, Hair et al. 2013, Daoud 2017). Hair et al. (2013) stated that the interpretation of relationships is complicated and made more chaotic with the presence of multicollinearity issues.

Due to the high levels of association between the independent variables, the risk of multicollinearity is high, and misleading results from the multiple regression analysis may be produced. The emerging of theory contradicting signs of regression coefficients (either positive or negative), where the coefficients take on negative values when either the theory or the Pearson correlation analysis suggests otherwise, has reinforced the belief about the existence of multicollinearity in this research.

In detail, the Pearson correlation coefficients among the manufacturing flexibility dimensions are statistically high and significant at $\alpha=0.01$ (the highest value registered being 0.788 between labor flexibility and material handling flexibility). Moreover, the regression models developed in this research indicated high adjusted R2 values (values between 0.533 and 0.663). In addition, F-statistics for the multiple regression model are statistically significant at $\alpha=0.05$ but the t-statistics indicate that only several of the manufacturing flexibility dimensions make a significant contribution to the dependent variable. Based on the above observations, it can be concluded that the presence of multicollinearity problems in the regression models examined in this research are inevitable.

The results of the Pearson correlation coefficients among the manufacturing flexibility dimensions that are statistically significant and positive have provided the foundation for the argument that the manufacturing flexibility dimensions should be implemented holistically. Also, in order to ensure content validity, a Principal Component Analysis (PCA) was used as a remedy to deal with the multicollinearity problem in the multiple regression analysis (Daoud 2017, Nahar et al. 2018). In other words, the principal compo- 
nent analysis, aimed at summarizing most of the original information in the minimum number of factors for prediction purposes, is also useful when used in conjunction with a simple regression method, as it addresses the multicollinearity problem in the multiple regression analysis (Hair et al. 2013, Abdi and Williams 2010, Daoud 2017, Nahar etal. 2018).

In short, due to the presence of the multicollinearity problem in the multiple regression analysis, the contribution of the independent variables to each dependent variable should be analyzed collectively with the help of the PCA, which will describe the interrelated independent variables as a unified set, rather than individually. When the interrelated independent models presented have regression coefficients that are statistically positive and significant at $\alpha=0.05$. This suggests that all the manufacturing flexibility dimensions collectively contribute to business performance, with $\mathrm{R} 2$ values ranging between $37.0 \%$ and $56.3 \%$. In detail, the implementation of the manufacturing flexibility dimensions significantly improve business performance, in terms of profitability, product market performance, and customer satisfaction. Thus, hypotheses $\mathrm{H}_{a}, \mathrm{H}_{\mathrm{b}}$ and $\mathrm{H}_{\mathrm{c}}$ are supported.

These scores are obtained from the linear combination of the relevant variables as described below. The first principal component or linear combination of the manufacturing flexibility dimensions (63.74\%

Table 8. Results of Simple Regression Analysis between the First Principal Component Score of Manufacturing Flexibility Dimensions and Business Performance Measures

\begin{tabular}{|c|c|c|c|c|c|c|}
\hline \multirow{2}{*}{ Model } & \multicolumn{2}{|c|}{ Unstandardized } & \multirow{2}{*}{$\begin{array}{l}\text { Standardized } \\
\text { Beta }\end{array}$} & \multirow{2}{*}{$\mathrm{t}$} & \multirow{2}{*}{ Sig. } & \multirow{2}{*}{$\mathbf{R} 2$} \\
\hline & Beta & Std. Error & & & & \\
\hline (Constant) & 0.299 & 0.307 & & 0.976 & 0.331 & \multirow{2}{*}{$0.563^{*}$} \\
\hline Regression & 0.359 & 0.027 & 0.750 & 13.178 & 0.000 & \\
\hline \multicolumn{7}{|c|}{ IV = PCA of Manufacturing Flexibility } \\
\hline \multicolumn{7}{|c|}{ DV $=$ Profitability } \\
\hline (Constant) & 0.801 & 0.368 & & 2.179 & 0.031 & \multirow{2}{*}{$0.370^{*}$} \\
\hline Regression & 0.291 & 0.033 & 0.608 & 8.906 & 0.000 & \\
\hline \multicolumn{7}{|c|}{ IV = PCA of Manufacturing Flexibility } \\
\hline \multicolumn{7}{|c|}{ DV = Product Market Performance } \\
\hline (Constant) & 0.940 & 0.293 & & 3.204 & 0.002 & \multirow{2}{*}{$0.509^{*}$} \\
\hline Regression & 0.308 & 0.026 & 0.713 & 11.826 & 0.000 & \\
\hline
\end{tabular}

IV = PCA of Manufacturing Flexibility

DV = Customer Satisfaction

IV = Independent variable; DV = Dependent variable; Principal component score is obtained from PCA; * F statistics are significant at the 0.05 level.

variables (whose suffer the multicollinearity issues) have been group into one unified set, the multicollinearity issue will have been addressed (Daoud 2017, Nahar et al. 2018).

The summary of the simple regression analysis is shown in Table 8 . The regression variance explained) is: 0.274 (mix flexibility) +0.360 (new product flexibility) +0.407 (labor flexibility) +0.383 (machine flexibility) +0.405 (material handling flexibility) + 0.381 (routing flexibility) +0.416 (volume flexibility). 
Table 9. Results of Simple Regression

\begin{tabular}{lc}
\hline \multirow{2}{*}{ Independent Variable } & Dependent Variable \\
\cline { 2 - 2 } Manufacturing Flexibility (MF) & Business Performance Standardized $\beta$ \\
\hline R2 & $0.782^{*}$ \\
\hline Adjusted R2 & 0.611 \\
\hline R2 change & 0.609 \\
\hline F change & 0.611 \\
\hline
\end{tabular}

*significant at $\mathrm{p}<0.05$

In addition, the first principal component or linear combination of business performance measures $(77.79 \%$ variance explained) is: 0.605 (profitability) +0.569 (productmarket performance) +0.558 (customer satisfaction).

From Table 9, the direct effect of manufacturing flexibility on business performance is high (0.782). The empirical evidence presented in this section indicates that manufacturing flexibility has a significant positive impact on a firm's business performance.

\section{Discussion and Conclusion}

Although manufacturing flexibility can be a critical source of competitive advantage, the poor understanding of how manufacturing flexibility can improve performance has plagued the efforts to strike for better manufacturing flexibility.

Based on the Pearson correlation analyses, all the dimensions of manufacturing flexibility are inter-correlated. With the emerging of theory contradicts sign in the multiple regression analyses, the existence of multicollinearity issues in the regression model is suggested. To compensate for these issues, a Principal Component Analysis (PCA) was used as a remedy, and the conclusion that manufacturing flexibility has a positive influence on business performance can be made.

This research is important as it addresses how manufacturing flexibility contributes to business performance and thus removes the obstacle that prevents manufacturing organizations from implementing the concept of manufacturing flexibility.

The overall conclusions, based on the findings, show that the manufacturing flexibility dimensions (collectively) are able to explain a significant percentage of the total variance in each of the measures of business performance measures (profitability, product market performance and customer satisfaction). Thus, enhancing the manufacturing flexibility dimensions is vital since manufacturing flexibility is found to have tremendous effects on busi-

Table 10. Summary of Hypotheses Testing for the Relationship between Manufacturing Flexibility Dimensions and Business Performance Measures

\begin{tabular}{ll}
\hline Hypotheses & Result \\
\hline $\mathrm{H}_{a}:$ Manufacturing flexibility dimensions have a positive relationship with profitability & Supported \\
\hline $\mathrm{H}_{\mathrm{b}}:$ Manufacturing flexibility dimensions have a positive relationship with product market & Supported \\
performance & \\
\hline $\begin{array}{l}\mathrm{H}_{\mathrm{c}}: \text { Manufacturing flexibility dimensions have a positive relationship with customer satis- } \\
\text { faction }\end{array}$ & Supported \\
\hline
\end{tabular}


ness performance. The next section will talk about the implications of the study.

\section{Implications of the Study}

Several implications of the study have been observed:

\section{Theoretical Implications}

A parsimonious set of manufacturing flexibility's dimensions (seven dimensions: mix flexibility, new product flexibility, labor flexibility, machine flexibility, material handling flexibility, routing flexibility and volume flexibility) have been suggested to serve as a foundation block for future studies.

Multicollinearity has been observed between the manufacturing flexibility's dimensions, so extra care should be given when exercising multiple regressions analyses on those dimensions.

The impact of manufacturing flexibility on business performance has been established in this study. Thus, it is safe to say that manufacturing flexibility, as a choice to gain a competitive advantage, has been verified.

This research contributes to the literature on manufacturing flexibility by providing a developing-country example of how manufacturing flexibility affects business performance.

\section{Managerial/Practical Implications}

This research provides insights into the impacts and influences of the manufacturing flexibility concept in a developing country scene. These provide a foundation for managers that seek a competitive advantage and process excellence in their organization to justify their actions to adopt manufacturing flexibility as an alternative best practice, aside from the conventional types of best practices.

The adoption of manufacturing flexibility in Malaysia is inevitably proven here. The researchers foresee more adopters of manufacturing flexibility as advantages of adopting this concept tabled.

Limitations and suggestions for future research will be presented in the nextsub-section.

\section{Limitations and Suggestions for Fu-} ture Research

\section{Limitations of the study}

All studies have limitations. Most of the previous surveys employed a general assumption in their data collection; this study suffers from the same limitations. In this research, two assumptions have been made:

The respondents who participated in the survey were assumed to have sufficient knowledge to answer the questionnaire. They answered the measurement items precisely and honestly.

Steps such as "sending questionnaires directed at executive management (who are most likely to have access to the relevant information)" have been taken to reduce the likelihood of the errors.

On the other hand, even though the product market performance (one of the business performance measures) registered a $90.78 \%$ percent of variance explained, more items can be added to better represent this performance indicator, thus improving its sampling adequacy. Suggestions for future research will be listed in the next section. 


\section{Suggestions for Future Research}

A few suggestions have been made for potential future studies, and they include:

To prevent respondent bias, future research can be done by using secondary data, instead of only using primary data.

This research focuses on the production areas of a firm, future research may include the exterior areas of the production floor, which include, but are not limited to, the supply chain, customer relationships etc.

This research employed regression analysis as the main analysis method to test for the relationship between manufacturing flexibility and business performance. For triangulation purposes, different data analysis methods such as Covariance-Based Structural Equation Modeling (CB-SEM) may be considered. CB-SEM is more concerned with explanations and is the appropriate method for theory testing. One can have more confidence in a result if the use of different techniques leads to similar results. However, the CB-SEM technique generally requires larger sample sizes, so future researchers should be aware of the constraints of time and the cost of adopting such a technique.

Furthermore, future research acknowledge the technology levels used by the firms is welcome, where sometimes the level of technology can influence the readiness of firms to adopt manufacturing flexibility.

Nevertheless, an examination of the validity of the set of manufacturing flexibility dimensions identified in this research, in oth- er contexts, such as services or a supply chain division, may also provide a feasible research avenue.

\section{Conclusion}

This research provides valuable insights for manufacturing firms into the impact of manufacturing flexibility, and its dimensions, on business performance. The results indicate that manufacturing flexibility, which comprises mix flexibility, new product flexibility, labor flexibility, machine flexibility, material handling flexibility, routing flexibility and volume flexibility, has a significant positive impact on business performance. Meanwhile, a parsimonious set of manufacturing flexibility's dimensions has been established for future studies. On the other hand, the multicollinearity of manufacturing flexibility's dimensions has been solved using a Principal Component Analysis (PCA) approach, and a developing country example of how manufacturing flexibility affects business performance is presented. This research hopes to be beneficial to companies in the manufacturing sectors. The findings of this study have supported the belief that manufacturing flexibility is a critical source for gaining a competitive advantage, and those firms that implement manufacturing flexibility will gain benefits in the long run. Nevertheless, the desire of managers to adopt manufacturing flexibility can be increased with a proven record of how manufacturing flexibility, as a manufacturing best practice, improves business performance. Finally, the researcher anticipates that the execution of this research would stimulate interest in this research subject, and foster more future research in this area. 


\section{References}

Abdi, Hervé, and Lynne J. Williams. 2010. "Principal component analysis." Wiley Interdisciplinary Reviews: Computational Statistics no. 2 (4):433-459. doi: 10.1002/wics.101.

Agus, Arawati. 2011. "Supply chain management, supply chain flexibility and business performance." Journal of Global Strategic Management no. 9:134-145.

Al-jawazneh, Bahjat Eid. 2012. "Manufacturing Flexibility and Operational Performance of Pharmaceutical Manufacturing Companies in Jordan." International Journal of Business and Management no. 7 (4):181-194. doi: 10.5539/ijbm.v7n4p181.

Brettel, Malte, Manuel Klein, and Niklas Friederichsen. 2016. "The Relevance of Manufacturing Flexibility in the Context of Industrie 4.0.” Procedia CIRP no. 41:105-110.

Carton, Robert B, and Charles W Hofer. 2006. Measuring organizational performance: Metrics for entrepreneurship and strategic management research. Cheltenham, UK: Edward Elgar Publishing.

Chang, Shih-Chia, Chen-Lung Yang, Hsin-Chia Cheng, and Chwen Sheu. 2003. "Manufacturing flexibility and business strategy: An empirical study of small and medium sized firms." International Journal of Production Economics no. 83 (1):13-26. doi: 10.1016/s09255273(02)00263-3.

Chauhan, Gulshan, and T. P. Singh. 2014. "Development and validation of resource flexibility measures for manufacturing industry." Journal of Industrial Engineering and Management no. 10 (1):21-41. doi: 10.3926/jiem.655.

Cooper, D., and P. Schindler. 2013. Business Research Methods. 12th ed. New York, NY: McGraw-Hill Higher Education.

Daoud, Jamal I. 2017. "Multicollinearity and Regression Analysis." Journal of Physics: Conference Series no. 949:012009. doi: 10.1088/1742-6596/949/1/012009.

Gupta, Yash P., and Toni M. Somers. 1996. "Business Strategy, Manufacturing Flexibility, and Organizational Performance Relationships: A Path Analysis Approach." Production and Operations Management no. 5 (3):204-233.

Hair, J.F., W.C. Black, B.J. Babin, and R.E. Anderson. 2013. Multivariate Data Analysis. 7th ed. UK: Pearson Education.

Helkiö, Pekka. 2008. International Investigation Of Manufacturing Flexibility: Strategies, Contingencies And Antecedents, Faculty of Information and Natural Sciences, Helsinki University Of Technology.

Indarti, Nurul. 2004. "Business Location and Success: The Case of Internet Café Business in Indonesia." Gadjah Mada International Journal of Business no. 6 (2):171-192.

Judi, Hairulliza Mohamad, and Roger Beach. 2008. "The Structure of Manufacturing Flexibility: Comparison Between UK and Malaysian Manufacturing Firms." Journal of Applied Sciences no. 8 (19):3340-3350. doi: 10.3923/jas.2008.3340.3350.

Judi, Hairulliza Mohamad, Roger Beach, and Alan Paul Muhlemann. 2004. Defining Manufacturing Flexibility: A Research Prerequiste. In Working Paper No. 04/38. UK: Bradford University School of Management.

Kaur, Shakun Preet, Jatinder Kumar, and Rakesh Kumar. 2016. "Impact of Flexibility of Manufacturing System Components on Competitiveness of SMEs in Northern India." Journal of Engineering, Project, and Production Management no. 6 (1):63.

Koste, Lori L., Manoj K. Malhotra, and Subhash Sharma. 2004. "Measuring dimensions of man- 
ufacturing flexibility." Journal of Operations Management no. 22 (2):171-196. doi: 10.1016/j. jom.2004.01.001.

Kuhn, Max, and Kjell Johnson. 2013. Applied Predictive Modeling. New York, NY: Springer-Verlag. Larso, Dwi, Toni Doolen, and Marla Hacker. 2009. "Development of a manufacturing flexibility hierarchy through factor and cluster analysis." Journal of Manufacturing Technology Management no. 20 (4):417-441. doi: 10.1108/17410380910953702.

Lucas, Marilyn T., and Olga M. Kirillova. 2011. "Reconciling the resource-based and competitive positioning perspectives on manufacturing flexibility." Journal of Manufacturing Technology Management no. 22 (2):189-203. doi: 10.1108/17410381111102216.

Mann, Robin, and Dennis Kehoe. 1994. "An Evaluation of the Effects of Quality Improvement Activities on Business Performance." International Journal of Quality \& Reliability Management no. 11 (4):29-44. doi: 10.1108/02656719410057935.

Miller, C. Chet, Nathan T. Washburn, and William H. Glick. 2013. "PERSPECTIVE-The Myth of Firm Performance." Organization Science no. 24 (3):948-964. doi: 10.1287/ orsc.1120.0762.

Mishra, Ruchi, Ashok K. Pundir, and L. Ganapathy. 2014. "Assessment of manufacturing flexibility.” Management Research Review no. 37 (8):750-776. doi: 10.1108/mrr-03-2013-0055.

Mishra, Ruchi, Ashok K. Pundir, and L. Ganapathy. 2016. "Conceptualizing sources, key concerns and critical factors for manufacturing flexibility adoption." Journal of Manufacturing Technology Management no. 27 (3):379-407. doi: 10.1108/jmtm-06-2015-0037.

Nahar, Julita, Sri Purwani, Sudradjat Supian, and Fatimah Khonsa Syahidah. 2018. "Overcoming the Multicollinearity by Using Principal Component Regression in Economic Growth Model." Journal of Engineering and Applied Sciences no. 13 (2):286-290. doi: 10.3923/jeasci.2018.286.290.

Narasimhan, Ram, and Ajay Das. 1999. "An Empirical Investigation of the Contribution of Strategic Sourcing to Manufacturing Flexibilities and Performance." Decision Sciences no. 30 (3):683-718. doi: 10.1111/j.1540-5915.1999.tb00903.x.

Nawanir, Gusman. 2011. Lean Practices, Operations Performance and Business Performance: A Study on Indonesia Manufacturing Companies, Othman Yeop Abdullah Graduate School of Business, Universiti Utara Malaysia.

Nawanir, Gusman, Kong Teong Lim, and Siti Norezam Othman. 2013. "Impact of lean practices on operations performance and business performance." Journal of Manufacturing Technology Management no. 24 (7):1019-1050. doi: 10.1108/jmtm-03-2012-0027.

Nishith, Mohan, Gupta Rishi, and S.K. Sharma. 2013. "Flexibility Measurement Criteria with Respect To Reconfigurable System Properties.” Int. Journal of Engineering Research and Applications no. 3 (5):1711-1716.

Pérez-Pérez, Marta, Ana- M. Serrano Bedia, María-Concepción López-Fernández, and Gema García-Piqueres. 2018. "Research opportunities on manufacturing flexibility domain: A review and theory-based research agenda." Journal of Manufacturing Systems no. 48:9-20. doi: 10.1016/j.jmsy.2018.05.009.

Pérez Pérez, Marta, Ana María Serrano Bedia, and María Concepción López Fernández. 2016. "A review of manufacturing flexibility: systematising the concept." International Journal of Production Research no. 54 (10):3133-3148. doi: 10.1080/00207543.2016.1138151. 
Ramasesh, Ranga V., and Maliyakal D. Jayakumar. 1991. "Measurement of manufacturing flexibility: A value based approach.” Journal of Operations Management no. 10 (4):446-468. doi: 10.1016/0272-6963(91)90005-i.

Richard, P. J., T. M. Devinney, G. S. Yip, and G. Johnson. 2009. "Measuring Organizational Performance: Towards Methodological Best Practice.” Journal of Management no. 35 (3):718804. doi: 10.1177/0149206308330560.

Roberts, P., and H. Priest. 2006. "Reliability and validity in research." Nurs Stand no. 20 (44):41-5. doi: 10.7748/ns2006.07.20.44.41.c6560.

Rogers, Pamela P. 2008. An empirical investigation of manufacturing flexibility and organizational performance as moderated by strategic integration and organizational infrastructure, University of North Texas.

Rogers, Pamela P., Divesh Ojha, and Richard E. White. 2011. "Conceptualising complementarities in manufacturing flexibility: a comprehensive view." International Journal of Production Research no. 49 (12):3767-3793. doi: 10.1080/00207543.2010.499116.

Russell, Roberta S., and Bernard W. Taylor. 2014. Operations and Supply Chain Management. 8th ed. Singapore: John Wiley \& Sons.

Santos, Juliana Bonomi, and Luiz Artur Ledur Brito. 2012. "Toward a subjective measurement model for firm performance." BAR. Brazilian Administration Review no. 9 (spe):95-117. doi: 10.1590/s1807-76922012000500007.

Saraph, Jayant V., P. George Benson, and Roger G. Schroeder. 1989. “An Instrument for Measuring the Critical Factors of Quality Management.” Decision Sciences no. 20 (4):810-829. doi: 10.1111/j.1540-5915.1989.tb01421.x.

Sekaran, U., and R. Bougie. 2013. Research Methods for Business: A Skill Building Approach. 6th ed. New York, NY: John Wiley \& Sons.

Sethi, AndreaKrasa, and SureshPal Sethi. 1990. "Flexibility in manufacturing: A survey." International Journal of Flexible Manufacturing Systems no. 2 (4):289-328. doi: 10.1007/bf00186471.

Shewchuk, John P., and Colin L. Moodie. 1998. "Definition and classification of manufacturing flexibility types and measures." International Journal of Flexible Manufacturing Systems no. 10 (4):325-349. doi: 10.1023/a:1008062220281.

Stevenson, William J. 2015. Operations Management. 12th ed. New York, NY: McGraw-Hill Education.

Swamidass, P. M., and W. T. Newell. 1987. "Manufacturing Strategy, Environmental Uncertainty and Performance: A Path Analytic Model." Management Science no. 33 (4):509-524. doi: 10.1287/mnsc.33.4.509.

Swink, Morgan, Ram Narasimhan, and Soo Wook Kim. 2005. "Manufacturing Practices and Strategy Integration: Effects on Cost Efficiency, Flexibility, and Market-Based Performance." Decision Sciences no. 36 (3):427-457. doi: 10.1111/j.1540-5414.2005.00079.x.

Vokurka, Robert J., and Scott W. O'Leary-Kelly. 2000. "A review of empirical research on manufacturing flexibility." Journal of Operations Management no. 18 (4):485-501. doi: 10.1016/ s0272-6963(00)00031-0.

Wikipedia. Market Share 2015. Available from https://en.wikipedia.org/wiki/Market_share.

Zhang, Qingyu, Mark A Vonderembse, and Jeen-Su Lim. 2003. "Manufacturing flexibility: defining and analyzing relationships among competence, capability, and customer satisfaction." 
Journal of Operations Management no. 21 (2):173-191. doi: 10.1016/S0272-6963(02)00067-0. Zikmund, W., B. Babin, J. Carr, and M. Griffin. 2013. Business Research Methods. Orlando, FL: Cengage Learning.

\section{Appendix I}

\begin{tabular}{|c|c|c|}
\hline Author and Year & Type of Study & Findings and Remarks \\
\hline Swamidass and Newell (1987) & Empirical Study & $\begin{array}{l}\text { Greater manufacturing flexibility provides better per- } \\
\text { formance results. }\end{array}$ \\
\hline Ramasesh and Jayakumar (1991) & Mathematic Modeling & $\begin{array}{l}\text { Different manufacturing flexibility dimensions affect } \\
\text { performance in dissimilar ways and the sets of man- } \\
\text { ufacturing flexibility dimensions create a combined } \\
\text { effect. }\end{array}$ \\
\hline Gupta and Somers (1996) & Empirical Study & $\begin{array}{l}\text { Inconsistent results regarding the impacts of man- } \\
\text { ufacturing flexibility on business performance have } \\
\text { been seen. }\end{array}$ \\
\hline Narasimhan and Das (1999) & Empirical Study & $\begin{array}{l}\text { New product flexibility has a positive relationship } \\
\text { with customer satisfaction. }\end{array}$ \\
\hline $\begin{array}{l}\text { Vokurka and O’Leary-Kelly } \\
(2000)\end{array}$ & Empirical Study & $\begin{array}{l}\text { Inconsistent evidence regarding the impact of manu- } \\
\text { facturing flexibility on business performance. }\end{array}$ \\
\hline Chang et al. (2003) & Empirical Study & $\begin{array}{l}\text { Inconsistent evidence regarding the impact of manu- } \\
\text { facturing flexibility on business performance. }\end{array}$ \\
\hline $\begin{array}{l}\text { Swink, Narasimhan, and Kim } \\
\text { (2005) }\end{array}$ & Empirical Study & $\begin{array}{l}\text { Both process and new product flexibilities have a pos- } \\
\text { itive impact on market-based performance. }\end{array}$ \\
\hline Rogers (2008) & Empirical Study & $\begin{array}{l}\text { Lack of understanding about the relationship be- } \\
\text { tween individual dimensions of manufacturing flex- } \\
\text { ibility and organizational performance create incon- } \\
\text { sistent results. }\end{array}$ \\
\hline Agus (2011) & Empirical Study & $\begin{array}{l}\text { Significant correlations occurred between supply } \\
\text { chain management, supply chain flexibility and busi- } \\
\text { ness performance. }\end{array}$ \\
\hline $\begin{array}{l}\text { Mishra, Pundir, and Ganapathy } \\
\text { (2014) }\end{array}$ & Literature Review & $\begin{array}{l}\text { Not all past research found that manufacturing flexi- } \\
\text { bility improves business performance. }\end{array}$ \\
\hline Pérez-Pérez et al. (2018) & Literature Review & $\begin{array}{l}\text { Plenty of research opportunities in the context of } \\
\text { manufacturing flexibility. }\end{array}$ \\
\hline
\end{tabular}

